\title{
Assessing the appropriateness of carbon financing for micro-scale projects in terms of capabilities
}

\author{
Caitlin Trethewy \\ School of Photovoltaic and Renewable Energy Engineering, UNSW, Sydney. \\ Caitlin.Trethewy@gmail.com
}

\begin{abstract}
Micro-scale development projects are currently underrepresented in global carbon markets. This paper outlines the process of becoming eligible to generate carbon credits and examines some of the barriers that may inhibit access to carbon markets. In particular, it focuses on barriers relating to the capacity and resources of the organisation developing the project. This approach represents a deviation from the standard discourse which has traditionally focused on barriers relating to the availability of up-front finance and the capacity of local public and private sector institutions required to participate in the carbon standard certification process. The paper contains an analysis of the carbon offset project cycle from which follows a discussion of potential capacityrelated barriers focusing on time, skills and resources. Recommendations are made as to how these may be overcome with a particular focus on the role of technical organisations in assisting project developers. Completed during 2012 this research comes at an interesting time for global carbon markets as the Kyoto Protocol's first commitment period ended in 2012 and negotiations have failed to produce and agreement that would commit major emitters to reductions targets from 2013 onward. Despite this, reducing greenhouse gas emissions has gained momentum on the national level and many governments are in the process of formulating and introducing emissions trading schemes.
\end{abstract}

KEYWORDS: Carbon credits, emissions trading, micro-scale projects, capacity building.

\section{INTRODUCTION}

Many of the world's poorest people live without access to basic services such as clean drinking water. Projects in the developing world deploying technologies that provide such services may benefit greatly from additional revenue related to the generation and sale of carbon credits. These credits can be sold into international carbon markets where they are a relatively cheap and attractive source of greenhouse gas abatement compared to emissions reduction projects in developed countries. This paper examines the prevalence of such project in carbon markets and barriers to their further participation.

\section{CARBON FINANCING FOR MICRO-SCALE PROJECTS}

Carbon financing is the revenue gained from the sale of carbon credits or "offsets" generated by a project. In order to generate carbon credits a project must become certified by a carbon standard. Once certified the project is consistently monitored throughout its crediting period to ensure that real emissions reductions take place. If the monitoring is successful then credits will be issued by the carbon standard's governing body at regular intervals (typically annually). Undergoing this process represents a major investment of time, resources and funds that may not pay itself off for many years. Any organisation considering carbon finance must carefully assess their ability to attain and manage certification.

There are a number of different carbon standards under which a project can become certified. This paper will focus on three of the most common. The Clean Development Mechanism (CDM) is part of the Kyoto Protocol and carbon credits generated under this standard can be sold into many emissions trading schemes (ETS) including the European Union ETS and the forthcoming Australian ETS. The Gold Standard Voluntary Emissions Reduction (VER) and the Verified Carbon Standard (VCS) are widely traded on voluntary carbon markets. Credits issued under these standards are not traded on regulatory carbon markets created by mandatory ETS but are instead 


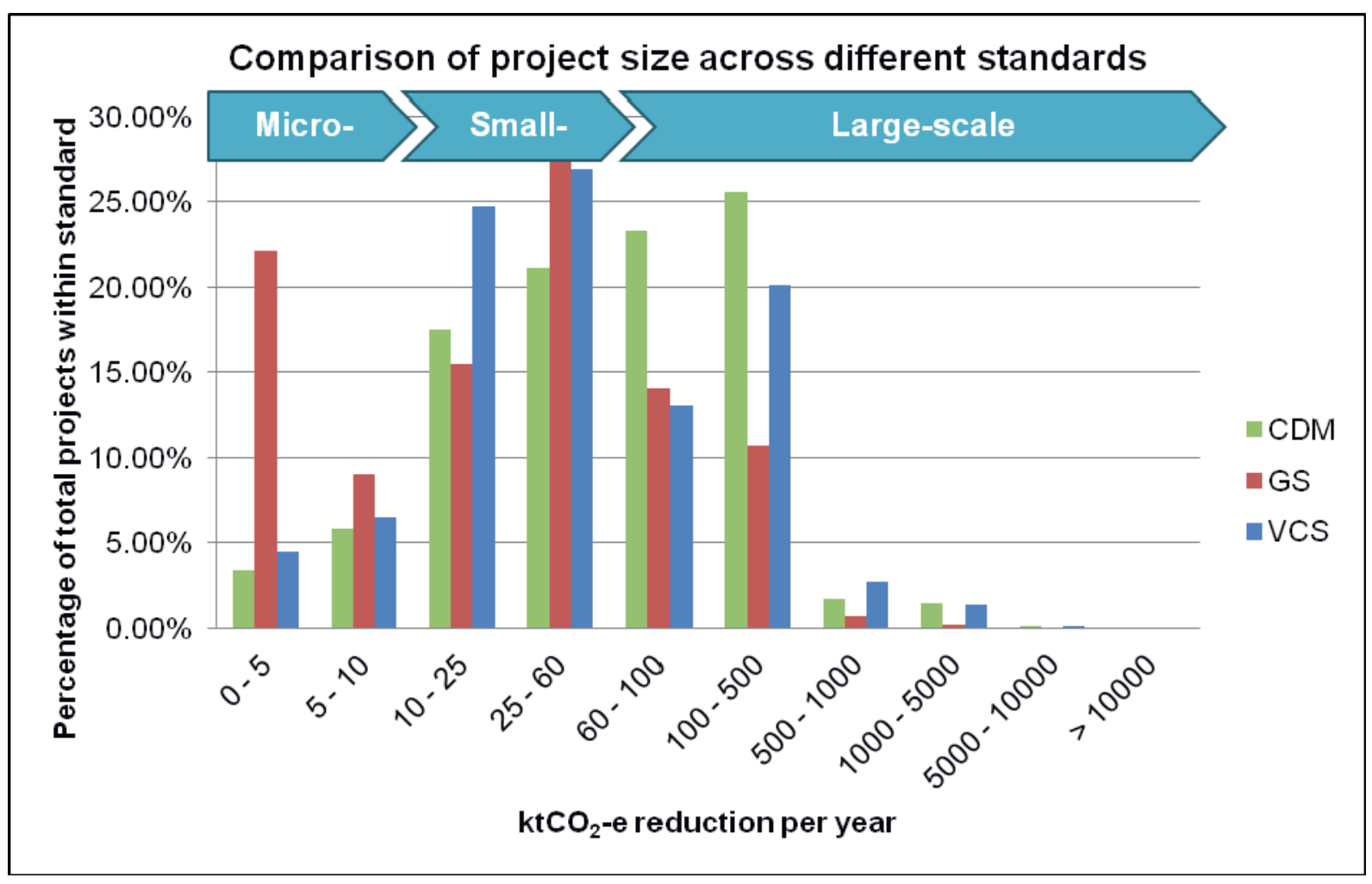

Figure 1: Comparison of project size across three different standards: data extracted from The Gold Standard Project Registry, 6 September 2012; The VCS Project Database, 5 September 2012 and The UNEP Risø CDM/JI Pipeline Analysis and Database, 1 August 2012.

purchased voluntarily by buyers. Accurate estimates of the voluntary carbon market are difficult to attain because most transactions are done over the counter. However, it is significantly smaller than the regulated carbon market which was valued at US\$176 billion in 2011 (Krossoy \& Guigon, 2012; Lafeld \& Velasquez, 2012; Peters-Stanley \& Hamilton, 2012). Voluntary buyers may be motivated by a variety of factors including corporate social responsibility, marketing, carbon neutrality and to gain experience working with carbon markets in anticipation of an upcoming mandatory emissions trading scheme (Peters-Stanley \& Hamilton, 2012). These varied motivations mean that some voluntary buyers are prepared to pay a premium to purchase carbon credits from projects that align with their own sustainable development values or offer a desirable marketing story (Bayon et al, 2007). The projects that Engineers Without Borders Australia is involved with would often fall into this category and so the voluntary carbon market may be more appropriate for them than the CDM. The involvement of a well-known Australian NGO, such as Engineers Without Borders (EWB), lends credibility to the project and may attract buyers who already support or know about the organisation. Thus, EWBs involvement with a project could expand the market for the carbon credits that is generates.

Despite the opportunities carbon financing presents, micro-scale projects are underrepresented in both voluntary and regulatory market carbon standards. This research focuses on micro-scale projects or programmes of activities that disseminate small pro-poor technology units, e.g. household or village scale units. Examples of this include household solar systems, water filters and small biogas digester units. Figure 1 shows the prevalence of micro-scale projects (defined as abating up to 10,000 tonnes of carbon dioxide equivalent per annum) in the three standards discussed. There are very few micro-scale projects in the CDM and VCS. The higher portion in the Gold Standard can be attributed to its special scheme for micro-scale projects which aims to reduce costs and streamline the certification process.

\section{BARRIERS TO CARBON FINANCING}

The small representation of micro-scale projects in global carbon markets can be attributed to a number of barriers that all projects face to some degree. These are exacerbated and often become inhibitive where micro-scale projects are undertaken by very small organisations (rather than large organisations undertaking multiple micro-scale projects). In these cases the skills and resources available to that project can be limited and the time available to acquire new skills may be very scarce.

The discourse surrounding barriers to carbon markets has traditionally focused on two main categories (Ellis et al, 2007; UNEP, 2007; Castro \& Michaelowa, 2011; Chadwick, 2006). Firstly, the cost of attaining carbon standard certification can inhibit 


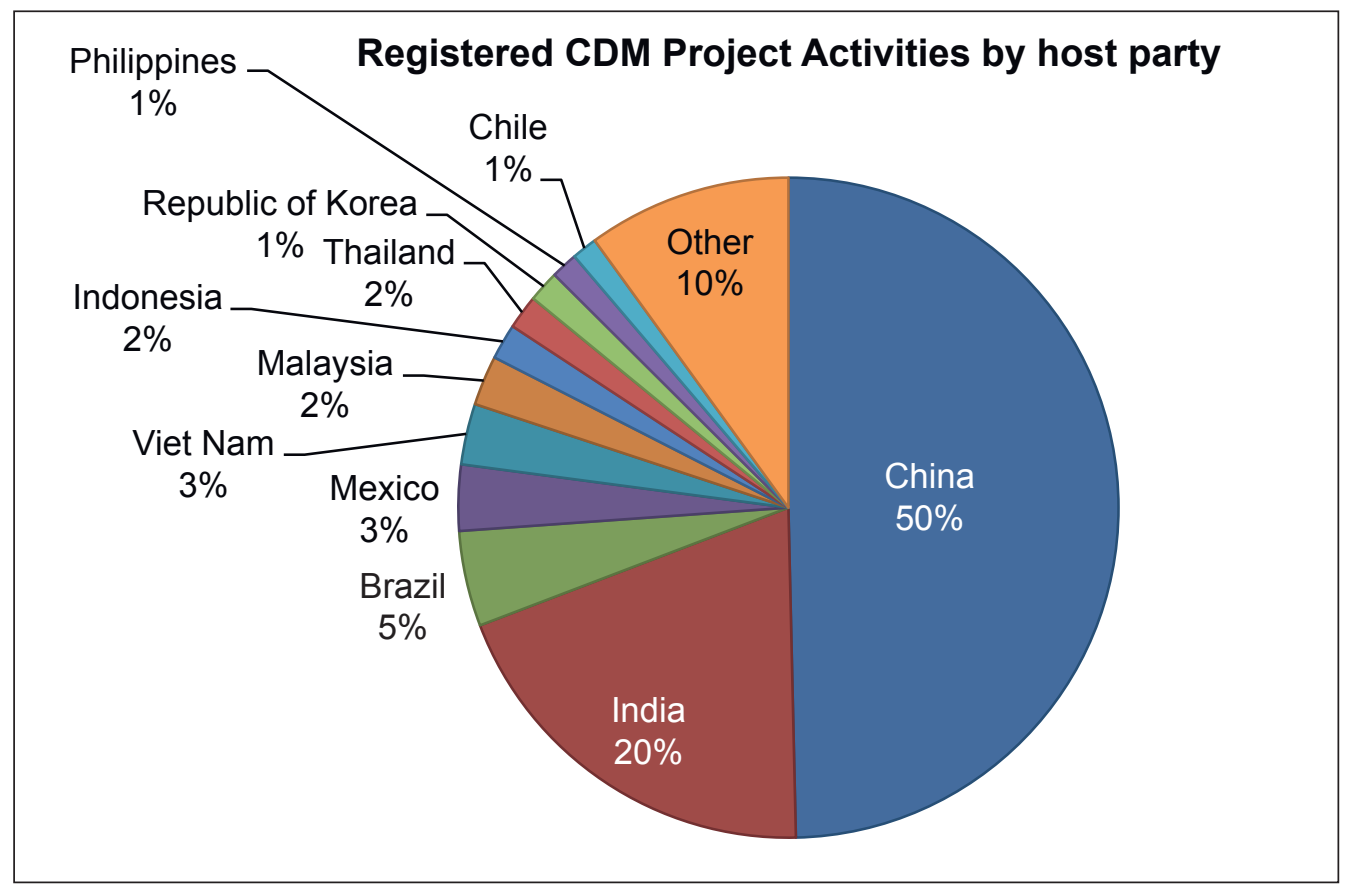

Figure 2: Global distribution of CDM project activities.

organisations from accessing carbon markets. It is not unusual for carbon standard certification to cost around US\$100K. However, it can cost significantly more depending on the particulars of the project, its location and the technology deployed. This poses a practical problem to carbon financing projects because transaction costs are typically incurred up-front while revenue from the sale of carbon credits is only generated after the project has been registered (Ellis et al, 2007). Many organisations, particularly those engaged in dispersing small propoor technology units such as water filters, may not have access to the capital required to make this investment.

Secondly, becoming certified to generate carbon credits requires the services of other public and private sector parties. This is a particular issue for projects working in least developed countries or rural communities. In some countries the relevant public sector institution lacks the capacity to effectively deal with carbon financing projects (Ellis et al, 2007; Castro \& Michaelowa, 2011). This is a particular issue for CDM projects which require to the host country government to have established a specific department (known as a Designated National Authority) that must approve all projects. In most carbon standards the project developer must engage the services of an independent third-party auditor. Finding an appropriately qualified auditor in the local area can be difficult and auditing fees can become very expensive if auditors need to travel from other countries or to rural areas. The importance of local private and public sector capacity cannot be overstated. Carbon financing projects are much more numerous in more industrialised nations such as China, India and Brazil, where this capacity has been developed while Least Developed Countries and in particular African countries are underrepresented as shown in Figure 2.

When determining the appropriateness of carbon financing for a proposed project, it is important to consider a whole range of factors. A thorough financial feasibility assessment is necessary to determine the risk and potential gains associated with investing in certification as opposed to undertaking the project without it. However, attaining carbon financing is not simply a matter of having the funds required to overcome transaction costs. Attaining and managing a carbon standard certification is likely to be very different from the organisation's core activities and require a significant investment of time and human resources. Many carbon financing projects are funded and assisted by multinational organisations with experience in gaining certification and selling carbon credits. However, for a small communitybased organisation undertaking a micro-scale project, capabilities could be a significant barrier.

\section{THE PROJECT CYCLE}

Detailed research of the carbon standard project cycle is undertaken to determine what skills and resources might be required to successfully access carbon markets. The capabilities required logically follow on from an understanding of the tasks required. There are some differences between the requirements of each carbon standard which can be an important 
factor in deciding which certification to pursue. For example, under the Gold Standard micro-scale projects benefit from streamlined rules making certification much simpler whereas the VCS and the $\mathrm{CDM}$ require them to undertake the same process are larger projects. Section 4 outlines the stages of the carbon standard project cycle that are considered.

\subsection{Pre-feasibility and eligibility}

Pre-feasibility is the stage at which the decision to pursue carbon financing must be made. A potential project is identified as eligible under the carbon standard and due diligence is undertaken to ensure that attaining carbon financing will be appropriate and that a project is likely to be approved by the standard. Undertaking further work is costly and a great deal of investment may be lost if a project is rejected by the governing body of the standard. Thorough investigations and due diligence at the pre-feasibility stage can minimise the risk of this occurring.

\subsection{New methodology approval}

A methodology is a document approved by the governing body of the carbon standard that outlines how the emissions reductions (or carbon credits generated) are to be calculated. In some cases a project technology is eligible under the carbon standard however there is not an existing standardised methodology. In these situations the project developer may develop their own methodology and apply for approval by the standard's governing body. This procedure is estimated to cost between US $\$ 20,000$ and US\$100,000 (Fenhann \& Hinostroza, 2011; UNEP, 2007; Ellis et al, 2007; Lafeld \& Velasquez, 2012). This research is directed at organisations that are not currently active in carbon markets, so developing a new methodology would likely be beyond their capability.

\subsection{Project initiation and project design document}

At this stage the project developer has decided to pursue carbon financing. They must complete and submit a number of forms to the governing body of the carbon standard. All carbon standards require the project developer (or a hired consultant) to complete a Project Design Document (PDD) form (referred to as a Project Description in VCS) which is available online. In this form the participant provides details of the project and how they will calculate emissions reductions.

If applying for CDM certification the project must be approved by a special government department within the host country known as the Designated National Authority (DNA). The Gold Standard requires the project developer to conduct two rounds of Local Stakeholder Consultation (LSC). The first is typically face-to-face and the second is done via the internet or mail to demonstrate that the project developer has address the issues raised in the first LSC.

\subsection{Validation}

The project is validated by an independent thirdparty accredited auditor. This normally includes a desktop review to confirm the documentation complies with the standard's rules and a site visit.

\subsection{Registration}

The auditor submits the validated project to the standard's governing body for registration. The documents are typically checked and vetted within the carbon standard's organisation before approval. Once the project is registered it can officially begin to generate emissions reductions.

\subsection{Monitoring}

The project participant must monitor the project activity according to their monitoring plan outlined in the PDD. Guidelines for monitoring are provided in the approved methodology. The methodology will also specify which of the parameters used to calculate emissions reductions must be determined through monitoring and surveys.

In the case of programmes of activities where units are dispersed over a wide area, a representative sample of units may be monitored. Project proponents must submit a sampling plan with their PDD in which they have undertaken statistical analysis to determine the sample size required to achieve the confidence/precision level required (CDM Executive Board, 2012). This plan is checked by the auditor at validation.

\subsection{Verification and certification}

An independent third-party auditor verifies that the emissions reductions occurred and monitoring was undertaken according to the plan. This step is normally undertaken annually and typically includes a desk review, the auditor may visit the site every few years (Kollmuss et al, 2008).

In the CDM and Gold Standard VER (large-scale projects only), validation and verification must be undertaken by different auditors in order to avoid conflicts of interest (The Gold Standard Foundation, 2012; Kollmuss et al, 2008). The VCS allows for validation and first verification to be undertaken at the same time by the same auditor. This assists in reducing the fees associated with hiring the auditor and streamlines the process because the auditor undertaking verification is already familiar with the project. 


\subsection{Credit issuance}

The auditor submits their verification report to the carbon standard with a request for the issuance of carbon credits. The report is typically checked and vetted by the standard before credits are issued.

Project proponents must have a registry account, which is a digital system used to keep track of all the carbon credits issued under a standard. Credits are issued to their registry account and traded digitally through the registry system.

\section{KEY ISSUES AND HOW THEY MAY BE ADDRESSED}

The analysis discussed in Section 4 is synthesised into the following key issues. Any organisation considering carbon finance for the first time should consider these issues and whether carbon finance would align with their current business model.

\subsection{Skills and human resources}

The organisation should consider whether or not they have the human resources to complete the tasks associated with certification and whether those people have the requisite skills. Guigon et al (2009) conducted interviews with consultants working in carbon financing to determine the time commitment required to attain certification under different carbon standards. Their estimate was around 100 days for the three standards under investigation. This work could be undertaken by someone in the organisation who may take longer than 100 days as it would probably be their first time doing this. They would need to have good English skills (reading and writing) as they would be required to read and complete form and documents. Basic excel spread sheet skills, including the use of functions, would be required to ensure they are able to make the necessary emissions reductions calculations.

Alternatively, the organisation could hire a professional consultant to do this at an estimated cost of $€ 1,000 /$ day (Guigon et al, 2009). It is possible to partner with a carbon finance consulting firm in an arrangement where they would handle the carbon financing component of the project in exchange for carbon credits at a reduced price when they become available. These agreements can be very competitive and firms often look for projects that are unique and low-risk with well-established and reliable development organisation.

There are many opportunities for technical organisations such as Engineers Without Borders to assist development organisations in this area. This assistance could include completing documentation and calculating emissions reductions according to an approved methodology which requires some mathematical ability. A key challenge may be the development of a monitoring plan and the statistical analysis required to determine what constitutes a representative sample for a programme of activities with many project units dispersed over a wide area, i.e. domestic or village-scale technologies. Statistical analysis may be very challenging for an organisation whose core business is the manufacture and/or distribution of a simple small-scale technology.

\subsection{Long lead times}

Gaining carbon standard certification is a lengthy process and will most likely take at least two years. It can be even longer in the case of projects that are in remote locations, using a relatively uncommon technology or experience delays in receiving approvals, finance or other services. Following certification it will typically be one year from registration until the project undergoes its first verification. If this is successful then credits will be issued. The organisation may start to receive income from the sale of carbon credits after three years; however, it could be even longer before this income repays the initial costs of certification. The crediting period of a project is typically 10 years (although 21 years can be selected in the CDM) so a financially feasible project must pay itself off in this time. Organisations considering carbon finance should seriously consider their capability and desire to lock-up capital for this length of time. In particular, this represents a very high risk for new organisations who may find it difficult to be certain that they would be in operation in 13 years. From the perspective of someone investing in a carbon financing project, an older organisation with a long track record of successful technology deployment would be much more attractive.

\subsection{Finance}

Becoming certified to generate carbon credits is expensive and as discussed in Section 5.2, money must be paid at the beginning that may not be redeemed for many years. It is very difficult to predict the cost of certification as it is dependent on a number of factors including project size, technology and location. There is very little information in the public domain that attempts to quantify the costs. A number of estimates were gathered from different sources and a range of possible costs can be given (UNEP, 2007; Ellis et al, 2007; Lafeld \& Velasquez, 2012; Guigon et al, 2009; Fenhann \& Hinostroza, 2011). The auditor's fees associated with validation and verification could cost between US\$5,000 and US $\$ 32,000$ per year. The other costs may be US $\$ 80,000$ to US $\$ 200,000$ over the life of the project but could be reduced if the organisation elected to do most of the work themselves rather than engaging an expert consultant.

The financial feasibility of the project must also 
be considered. It is not always the case that the income from carbon credits will cover the cost of certification. This is a particular issue for micro-scale projects because they are less likely to generate a large volume of credits than larger projects however their certification costs are not significantly less than larger projects. Detailed financial due diligence is required before going ahead with carbon financing, the financial risk is incredibly high as the organisation could lose the up-front money if it is unsuccessful in gaining certification.

\subsection{Physical resources}

The necessary physical resources generally relate to communications and monitoring. The organisation would require an Internet connection and telephone in order to liaise with auditors, the standard's governing body and key stakeholders. Monitoring of the project units must be undertaken at least every two years. This will require some form of transport and may be very time-consuming if the units are dispersed over a wide geographical area.

\subsection{Understanding of the potential benefits of carbon financing}

A case study of Resource Development International Cambodia (RDIC) provided further insight into the issues of capabilities and elucidated a number of key issues. An assessment of the appropriateness of carbon financing for RDIC at different project scales was conducted.

Overall the feedback from RDIC and volunteers from Engineers Without Borders (EWB) who assisted in completing the assessment that organisations that have no previous experience and knowledge of carbon financing require motivation to undertake the assessment process. Carbon financing is still a fairly new and niche area so many organisations may not be aware of how it can benefit their activities. Raising awareness and assisting organisations in being able to identify carbon financing opportunities is an important part of increasing the participation of micro-scale projects.

There is also an opportunity to use the networks of organisations like Engineers Without Borders to create a support community and facilitate knowledge transfer between organisations undertaking microscale projects. In addition to encouraging more organisations to investigate carbon financing this knowledge transfer may be able to bring more transparency to estimates of the transaction costs of certification for micro-scale projects.

\subsection{Document management}

It was difficult for one person to provide the requisite information to conduct a study of financial feasibility. Documentation has historically been a low priority for RDIC and there was no centralised collection or storage of information that was readily accessible (McDonald, 2012). This is probably the case in many micro-scale organisations as time and resources are typically stretched and documentation is not perceived as a high priority as it rarely delivers immediate benefits. However, carbon financing requires the management of significant documentation over a protracted period for which organisations that have no experience with document management would likely find problematic. Moreover, it may be difficult for an NGO to partner with another organisation such as a carbon credit wholesaler who would fund the up-front transaction costs of carbon financing in exchange for carbon credits at a discount when they become available later on. Such an organisation may make a US\$100-200K investment in an NGO and would therefore require evidence of a proven track record of successful and documented project completion, as abandonment of a project at any stage would result in significant losses (Lafeld \& Velasquez, 2012).

\section{CONCLUSION}

Micro-scale projects are currently underrepresented in global carbon markets because of a variety of barriers that inhibit their access to carbon finance. Lack of upfront capital finance and local public and private sector capacity are two key barriers discussed extensively in the literature. This paper has focused on a third category of barrier; the capacity of the organisation developing the project to achieve and maintain carbon standard certification. It has raised some key issues that organisations should consider when investigating carbon financing opportunities including the availability of time, staff, skills and physical resources. Moreover, there are many ways that technical organisations such as EWB can assist in addressing these barriers. Most notably, raising awareness about the opportunities presented by carbon financing for micro-scale projects could be highly beneficial to development organisations.

\section{ACKNOWLEDGEMENTS}

Many thanks are due to the following people without whom this project would not have been possible; Ian Cunningham, Jai Allison and Rasika Mohan from Engineers Without Borders Australia; Phil Cohn of RAMP Carbon; Anna Bruce from the University of New South Wales; Rene Velasquez and Dr Sascha Lafeld of First Climate. Resource Development International Cambodia provided significant feedback on the research and outcomes of this project. Many thanks are due to the EWB volunteers and RDIC staff involved; Megan McDonald; Ajay Chouhan and Ponloeu. 


\section{REFERENCES}

Bayon, R., Hawn, A. \& Hamilton, K. 2007, Voluntary Carbon Markets, London, Earthscan.

Castro, P. \& Michaelowa, A. 2011, “Would preferential access measures be sufficient to overcome current barriers to CDM projects in least developed countries?", Climate and Development, 3, 123-142.

CDM Executive Board. 2012, Standard for Sampling and Surveys for CDM Project Activities and Programme of Activities Version 3.0 [Online]. United Nations Framework Convention on Climate Change, Available: http:/ / cdm.unfccc.int/Reference / Standards/meth/meth_stan05.pdf [Accessed 4 October 2012].

Chadwick, B. 2006, "Transaction costs and the clean development mechanism", Natural Resources Forum, 30, 256-271.

Ellis, J., Oecd, Kamel, S. \& UNEP Riso Centre 2007, "Overcoming Barriers to Clean Development Mechanism Projects". Paris: Organisation for Economic Co-operation and Development, International Energy Agency and UNEP Riso Centre.

Fenhann, J. \& Hinostroza, M. 2011, CDM Information and Guidebook, Third Edition. Roskilde, Denmark: UNEP Risoe Centre and EU ACP MEA/CDM Programme.

Guigon, P., Bellassen, V. \& Ambrosi, P. 2009, Voluntary Carbon Markets: What the Standards Say [Online]. CDC Climat. Available: http:/ / www.cdcclimat. com/IMG/pdf/4_Working_Paper_EN_Voluntary_ carbon_markets_what_the_standards_say-2.pdf [Accessed 3 March 2012].
Kollmuss, A., Zink, H. \& Polycarp, C. 2008, "Making Sense of the Voluntary Carbon Market: A Comparison of Carbon Offset Standards". WWF Germany, Stockholm Environment Institute and Tricorona.

Krossoy, A. \& Guigon, P. 2012, State and Trends of the Carbon Market 2012 [Online]. Washington DC: Carbon Finance at The World Bank. Available: http:/ / siteresources.worldbank.org/ INTCARBONFINANCE/Resources / State_and_ Trends_2012_Web_Optimized_19035_Cvr\&Txt_ LR.pdf [Accessed 2 July 2012].

Lafeld, S. \& Velaquez, R. 20 August 2012; RE: Interview with Dr Sascha Lafeld and Rene Velasquez of First Climate. Type to Caitlin Trethewy.

McDonald, M. 27 September 2012, RE: Feedback from Resource Development International Cambodia and Engineers Without Borders on Carbon Financing Tool. Type to Trethewy, C.

Peters-Stanley, M. \& Hamilton, K. 2012, Developing Dimension: State of the Voluntary Carbon Markets 2012 [Online]. Ecosystem Marketplace \& Bloomberg New Energy Finance. Available: http://www. forest-trends.org/documents/files/doc_3164.pdf [Accessed 3 July 2012].

The Gold Standard Foundation. 2012, The Gold Standard Requirements Version 2.2 [Online]. GenevaCointrin Available: http:/ / www.cdmgoldstandard. org / wp-content / uploads / 2012 / 06 / GSv2.2_ Requirements.pdf [Accessed 28 September 2012].

UNEP 2007, Guidebook to Financing CDM Projects, In: Capacity Development for the Clean Development Mechanism (ed.). 
